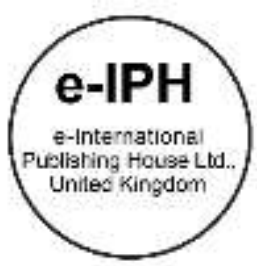

\title{
Street Vending in Urban Street Corridor in Medan, Indonesia: Potency or Problem?
}

\author{
Wahyuni Zahrah¹, Achmad Delianur Nasution² \\ 1,2Department of Architecture, Faculty of Engineering, \\ Universitas Sumatera Utara, Indonesia \\ Email of All Authors:wahyuni.zahra@usu.ac.id; aan.nasution@gmail.com \\ Tel of 1st Author: +62 81361238982
}

\begin{abstract}
This paper is aimed to investigate the role of street vending to support public life in the urban street. The study took place in three shop houses corridors in Medan, i.e., Asia, Kapten Muslim, and Ring Road Corridor. The research used the descriptive-exploratory method that collected qualitative and quantitative data. The exploration found that the street vending spots became the only place for social interaction, but not so intensive. The study pointed out to accommodate the street vending in a particular space of the corridor, in line with the re-arrangement of the whole area of the street to be a more human-friendly public space.
\end{abstract}

Keywords: street vending; urban street; public life; Medan

eISSN: 2398-4287@ 2019. The Authors. Published for AMER ABRA cE-Bsby e-International Publishing House, Ltd., UK. This is an open access article under the CC BYNC-ND license (http://creativecommons.org/licenses/by-nc-nd/4.0). Peer-review under responsibility of AMER (Association of Malaysian Environment-Behaviour Researchers), ABRA (Association of Behavioural Researchers on Asians) and cE-Bs (Centre for Environment-Behaviour Studies), Faculty of Architecture, Planning \& Surveying, UniversitiTeknologi MARA, Malaysia.

DOI: https://doi.org/10.21834/e-bpj.v4i10.1623

\subsection{Introduction}

In the midst of the condition of a lack of public open space in the form of parks and squares, the street corridor has the opportunity to become a public open space. Astreet corridor is a city space formed between two sides of a row of buildings, consisting of a building border area, a pedestrian pathway, a green lane, and a vehicle circulation path. Part of the road corridor that can be used as a place for communal activities is mainly pedestrian lines, although the border area still allows accommodatingcollective activities. When cities in Indonesia generally develop linearly, the center of community activities spills onto the street. On the pathway, residents circulate with various modes; people buy their daily needs. With these two main activities, circulation and buying and selling, this area became the place where people gather and made interaction.

Most of the street corridors in Medan, Indonesia, are filled with commercial functions, both retail trade and services. This commercial function can be found not only in buildings, but also in public open spaces, namely pedestrian lanes, and part of the street body. This area is often filled by street vendors, who are part of the economic activities of the informal sector. There are so many street vendors on each street, indicating that they are significant in "enlivening" that place, as a public open space. Therefore, it is necessary to examine how the role of street vendors in supporting public life on the area.

\subsection{Purpose of the study}

This research is intended to investigate the existence of street vendors in supporting public life in the street corridor. This analysis is useful for formulating the planning and design of street corridor spaces, as public open spaces, which are responsive to the needs of the community. 


\subsection{0bjective of the study}

The purpose of this study was to identify the public life that took place on the street associated with the presence of street vendors. To analyze community perceptions of street vendors, how street vendors perceive their presence at the public space, and how street vendors occupy space.

\subsection{Literature review}

Street vendors are widely defined as someone who offers merchandise to the public without having a fixed place of trade (Bhowmik, 2005). The existence of street vendors is growing fast in Southeast Asian countries, including Indonesia, which is generally caused by the lack of available employment. In many places, street vendors are considered illegal, although some city governments, such as the governments of Malaysia, Thailand, and Singapore, are trying to impose a registration system, those who are not registered are more numerous. One proof that they are not accepted in the city activity system is the unavailability of specific space to accommodate them.

The street vendors often occupy public spaces, such as parks, squares, and streets. The reason for choosing a location is related to several aspects, such as the existence of the place, public facilities, housing and consumers (Budiani, 2010). They also pay attention to strategic locations, activities, accessibility, and convenience (Widjajanti, 2015). Consideration of these aspects can be seen as 'match' with the existence of the street. A Street is a public space, and easily accessible. There are many prospective customers who pass every day, a strategic location because they can deal directly with potential customers.

In many kinds of literature, a street is not seen as merely a circulation space, but rather a place that should stimulate public life: the interaction between members of the community, the place where recreational activities take place which nourishes the body and refreshes the soul. All of these, are important activities that contribute to the maintenance and improvement of the quality of life (Chiesura, 2004; Nasution and Zahrah, 2014). That is, public space is said to be successful if the activity takes place well. In Medan, Indonesia, more public life takes place in parks or fields, which are limited in number. Public life that takes place on the streets is more commonly found in spontaneous settlements of middle and lower communities (Nasution and Zahrah, 2013). Meanwhile, this urban area are planned and used more to accommodate motorized vehicles than humans (Zahrah et al., 2016). Such characters are also found in other cities, such as in Nairobi, Kenya (Njeru and Kinoshita, 2018), and in Malaysia (Rahman et al., 2018). In the midst of the issue of imbalance between the space of vehicles and humans, the presence of street vendors adds to the density of street space. How the role of this sector for public life in the streets of Medan is essential to be explored to see the extent to which this place serves as a space for the community. The existence of street vendors who physically add 'lively' a street must be looked upwisely because it is usually always considered illegal and disturbing (Sun et al., 2018). This study will be useful in recommending the presence of street vendors in the street corridor design that more responsive to community needs.

\subsection{Methodology}

\subsection{Study area}

This research is located in three commercial corridors in Medan where the buildings are dominated by shop houses, namely

1. Shophouse Corridor in Jalan Asia

2. Shophouse Corridor Jalan Captain Muslim

3. Shophouse Corridor in Jalan Gagak Hitam/Ringroad

\subsection{Data collection}

There were 189 respondents

The data collected consists of:

a. Data on corridor settings; to describe the physical quality of existing public open spaces and surrounding areas, includes the border area, a pedestrian lane, and vehicle circulation path. Data collection was carried out by field mapping through visual surveys.

b. Activity data that takes place in the corridor, was carried out by field observations at the peak hours of activity, namely afternoon, evening and evening.

c. Data on motives, perceptions, and intensity of community activities related to street vendors. It was conducted by questionnairebased interviews with people who are on the move in the street vendor area. There were 189 respondents that chosen proportionally in each activities area.

d. Data on motives and perceptions of street vendors on their activities in public open spaces were conducted by questionnairebased interviews. Respondents were 23 street vendors who were active in the corridor.

e. The pattern of using public open space by street vendors is recorded by field observation.

\subsection{Data analysis}

The analysis was a descriptive-explorative approach. Public life is explained by a description of the type, intensity, and actors of activities that take place. Furthermore, it also described how the community interacted with street vendors and whether the street vendors supported community public life. Likewise, it is also explained how street vendors think about their involvement in communal activities and how the pattern of space occurs as a basis for formulating recommendations for planning and / or restructuring the corridor. The quantitative data were analyzed as the descriptive statistic by using MicrosoftExcel. 


\subsection{Findings}

\subsection{Corridor setting and street vending distribution}

The term "setting" was used to see how the physical condition of the corridor space as public open space. In the Asia corridor, almost all buildings had no setback. Then community activities took place on pedestrian and street lanes. The existing pedestrian track had dimensions of 1.2 - 1.5 meters, the material was concrete-block, but not continuous. As long as the path was not always flat, it was broken and did not have the same height. There was not much street furniture, except for a few lights and street markings. The same thing was also seen in the Muslim Captain Corridor. In this corridor, some segments did not even have pedestrian lanes at all. The condition was also no different, not continuous with several points of damaged material. On the ring-road corridor, as the city's primary arterial street, the pedestrian lane merged with the building's border area.

Street vendors along the corridor had different densities in each study location. The area with the most street vendors was in Kapten Muslim. They generally used building demarcation areas, and / or pedestrian lines, and or some vehicle circulation paths. That was street vendors who were supposed to get a place in the border of a building. They could expand their trading area to the sidewalk and the street. Some merchants who occupied the border area put up their trading information boards in public areas, both pedestrian and vehicle lanes. These types of street vendors generally got permission to use space by building owners. Traders who used public areas, both pedestrian and vehicle lanes, choose their own trading area without being based on one rule. Those who claimed first one part of space "had the right" to the place and determined their territory by themselves.

\subsection{Public life in the street corridor}

Activities carried out by people generally shopping for their needs, both in a shop house, as well as in the locations of street vendors. Very few came to the place to relaxor interact with friends or family. The results of behavioral mapping showed that the street corridor was more dominated by vehicles. Most of the residents came by using vehicles, especially motorbikes. It was not often to find pedestrians walking. If there were any, they did not use the sidewalk, but on the edge of the street. More interaction took place in shop buildings, especially in restaurant functions.

In addition, activities also took place at the points of street vendors. People who shopped at street vendors' locations consisted of two types. The first was sitting at the street vendor location, especially food / beverage traders. They came not alone, but with a partner, family or friends. This type had the opportunity to sit and relaxed while interacting with each other. The second type was those who only shopped, without sitting on the street vendor location. They bought something by a drive-in or drive-through. They just bought their needs and then left. The interactions that occurred were more limited only between buyers and street vendors. Other general activities were mostly seen as necessary actions, based on Gehl(1996), such as waiting for public transportation, community movements from vehicles to buildings, parking activities. It was seldom to find recreational activities (optional activities based on Gehl, 1996). It could be said that the interest was dominated by two things: first, the economic activities of street vendors, and second, the action of vehicle users. And, for example, parking a vehicle, for example, could take place on a pedestrian track, which should only be a pedestrian path.

\subsection{People perception of street vending}

Based on questionnaire-based interviews conducted on people who were active in the corridor, the fact indicated that the motives of the people who came to the area were mostly to shop for their needs. It was a very little portion that came for relaxation, or interaction with family or friends. Those who went to the stalls of street vendors also showed similar conditions. It was very few to see people moved toward the street vendor area to sit. Most of them stopped at the street vendor point, bought their needs and then left.

Most people explained that their motives were shopping at street vendors because of low prices and easy access. Most of them bought something in street vendor because of the location was in their route. The community believed that the existence of street vendors helped them to meet their needs, and knew and was aware that the position of street vendors in public areas was more or less disrupting community activities, both pedestrians and vehicle users (Table 1). They assumed that street vendors could trade in the communal space with terms and conditions.

Table 1. Characteristics of street vendors' customers and their perception of street vending

\begin{tabular}{|c|c|c|}
\hline NO & CRITERIA & PERCENTAGE \\
\hline \multirow{5}{*}{1} & How often do you shop in a street vendor in this corridor? & \\
\hline & a. Everyday & $7.50 \%$ \\
\hline & b. less than 2 times a week & $32.50 \%$ \\
\hline & c more than 2 times a week & $17.50 \%$ \\
\hline & d. very rarely & $42.50 \%$ \\
\hline \multirow{8}{*}{2} & What is your motivation to shop in the street vendor in this corridor? & \\
\hline & a. to get goods I need & $4.55 \%$ \\
\hline & b. cheap & $22.73 \%$ \\
\hline & C. near & $27.27 \%$ \\
\hline & d. easy & $4.55 \%$ \\
\hline & e. can be done while passing by & $34.09 \%$ \\
\hline & f. gathering with family/friends & $2.27 \%$ \\
\hline & g. others & $4.55 \%$ \\
\hline
\end{tabular}




\begin{tabular}{|c|c|c|}
\hline \multirow{3}{*}{3} & \multicolumn{2}{|l|}{ The way shopping in the street vendor } \\
\hline & a. get down from cars & $82.50 \%$ \\
\hline & b. drive in/ drive through & $17.50 \%$ \\
\hline \multirow{3}{*}{4} & Do you agree on shopping by drive through? & \\
\hline & a. Yes & $90.00 \%$ \\
\hline & b. No & $10.00 \%$ \\
\hline \multirow{3}{*}{5} & Do you agree that street vendor bothers the pedestrians? & \\
\hline & a. Yes & $90.00 \%$ \\
\hline & b. No & $10.00 \%$ \\
\hline \multirow{3}{*}{6} & Do you agree that street vendor interferes the traffic? & \\
\hline & a. Yes & $82.50 \%$ \\
\hline & b. No & $17.50 \%$ \\
\hline
\end{tabular}

\subsection{Street vendor perception to the street as a public space}

Traders who took place in municipal spaces generally argued that the area was easily accessible to prospective buyers. Some of them said that they did business there because it was close to where they live. Most street vendors relied on their core livelihood from selling in urban spaces. Some of them had been hereditary selling there, even to the third generation. Almost all street vendors argued that they had the right to occupy public space because it had been going on for years. There is no specific rule for choosing a location. If taking place in the building's border area (which often extends to the sidewalk and street body), traders communicated with the shop owner. However, most of them choose their own trading area (Table 2).

Table 2. Street vendors' characteristics and their perception of their activities in public space

\begin{tabular}{|c|c|c|}
\hline NO & CRITERIA & PERCENTAGE \\
\hline \multirow{5}{*}{1} & How often to sell here & \\
\hline & a. Every day & $72.73 \%$ \\
\hline & b. Working days only & $21.21 \%$ \\
\hline & c. Weekend only & $0 \%$ \\
\hline & d. Not necessarily & $6.06 \%$ \\
\hline \multirow{6}{*}{3} & Reasons to sell in this street corridor & \\
\hline & a. Crowded & $59.09 \%$ \\
\hline & b. Quiet & $4.55 \%$ \\
\hline & c. Safe & $11.36 \%$ \\
\hline & d, Close to home & $22.73 \%$ \\
\hline & e. Other & $2.27 \%$ \\
\hline \multirow{3}{*}{6} & Is selling the only income here & \\
\hline & a. Yes & $60.61 \%$ \\
\hline & b. Not & $39.39 \%$ \\
\hline \multirow{3}{*}{7} & Do you pay to sell here & \\
\hline & a. Yes & $39.39 \%$ \\
\hline & b. Not & $6 ., 61 \%$ \\
\hline \multirow{5}{*}{8} & If yes to whom & \\
\hline & a. Local youth / other non-government organizations & $40.00 \%$ \\
\hline & b. Government & $10.00 \%$ \\
\hline & c. Staff / government officials on duty & $20.00 \%$ \\
\hline & d. Shop owner & $30.00 \%$ \\
\hline \multirow{4}{*}{10} & Who chooses the location to sell & \\
\hline & a. Choose yourself & $90.91 \%$ \\
\hline & b. Agreement with fellow traders & $9.09 \%$ \\
\hline & c. Determined by local youth / other non-government organizations & $0 \%$ \\
\hline \multirow{3}{*}{12} & Do you agree that shopping from inside the vehicle (drive through) & ow of traffic \\
\hline & a. Yes & $57.58 \%$ \\
\hline & b. Not & $42.42 \%$ \\
\hline \multirow{3}{*}{13} & Do agree to sell on the sidewalk to disturb pedestrians & \\
\hline & a. Yes & $66.67 \%$ \\
\hline & b. Not & $33.33 \%$ \\
\hline \multirow{3}{*}{14} & Do you agree to sell on the street to disrupt the smooth flow of traffic & \\
\hline & a. Yes & $60.61 \%$ \\
\hline & b. Not & $39.39 \%$ \\
\hline \multirow{3}{*}{15} & Do you want to continue selling here & \\
\hline & a. Yes & $87.88 \%$ \\
\hline & b. Not & $12.12 \%$ \\
\hline
\end{tabular}




\subsection{Discussion}

\subsection{Quality of street, public life, and street vending}

In the three corridors in the study, it was shown that community activities were more of a necessary activity as the category proposed by Gehl (1996). Actions that were optional and recreational, according to Gehl (1996) related to the physical quality of public spaces. The better the place, the more recreational activities. This could be seen in the three corridors which showed that street space as a communal space, especially pedestrians, was not well designed, and recreational activities were very rarely found. The community only came to buy their needs, then went on. There was no motivation to "enjoy surroundings." This was related to the condition of space that was not user-friendly (Rahman, Sakip and Nayan, 2018). In the midst of this situation, the presence of street vendors provided facilities that were not available in the street space, especially seating, even though the conditions were not so good, and the location often intervened in sidewalks and circulation path. It was looked that the quality of facilities was not always relate to its usability. Even though only a small percentage of the people came to 'sit and relax' here, this was probably due to the presence of street vendors. The low quality of the pedestrian path, some were actually used for motorized parking vehicles and obstructing pedestrians right to use them. On the other hand, street vendors had the opportunity to become an outdoor seating area where people could eat while chatting because there were no such facilities in the pedestrian area. That was, street vendors had a contribution in supporting public life in the street corridor.

\subsection{People perception of street vending}

The results of the study showed that most respondents knew and realized that the presence of street vendors disturbed the pedestrian and smooth traffic. But on the other hand, they also argued that street vendors provided what they need. With limited space and facilities, most people agreed to drive through shopping which could disrupt the flow of traffic. From this fact, there was a discrepancy between knowledge and practice. Most respondents ignored theirunderstanding about potential circulation disruptions by street vendors and continued shopping at the place. This kind of thing could not be solved only in the design of space, but it should be by law and regulation enforcement. In Bandung, for example, the mayor set fines for buyers who shopped at street vendors in the illegal locations. And this had succeeded in creating a more orderly city space while still accommodating street vendors in the corridor design (Permana, Aziz and Siong, 2016).

\subsection{Street vending perception to the street as a public space}

Street vendors who filled the street corridors in the three study locations indicated that they sell there every day. Most of them depended on their income from trading as street vendors. Generally, they choose sites to sell in the corridor because it was a crowded place, making it easier to find consumers. Another reason was that it was near to their residence and safe, so they could sell for years. This condition was in line with other studies regarding the consideration of street vendors who choose public space (Budiani, 2010; Widjajanti, 2015). As consumers, the facts showed that street vendors also knew that they could disrupt community activities, but also wanted to continue selling in the corridor. The existence should be taken into consideration in planning and designing public spaces.

\subsection{Limitation of the study}

This study obtained data from respondents who were active in the corridor, to get to know more deeply the characteristics of street vendors and their customers who were using public space. The study was also explorative to explore phenomena at the study site and could not be a reference for generalization. The investigation that involved more respondents of household survey is expected to provide more facts about the interaction between street vendors and public life in the street corridor.

\subsection{Conclusion and recommendation}

This paper describes how the existence of street vendors, on the one hand, supported public life in the street corridor by providing a place for people to interact. On the other hand, both consumers and street vendors knew that their existence had the potential to disrupt the activities of the community, especially pedestrians. This was the effect of three things; firstly, the absence of planning that continues with supervision by the City Government, 'rejection' of street vendors in city space, and the gap between knowledge and practice due to two previous factors. It is recommended to accept the existence of street vendors in the design of the corridor, while still considering the top priority for pedestrian activity and traffic. However, planning should be accompanied by public education and law enforcement, so that all stakeholders know their rights and obligations in the city space which should be shared and used together.

\section{Acknowledgments}

The author expresses his gratitude and appreciation to the Republic of Indonesia Ministry of Research and Higher Education for providing research grants through the 2018 Contract Number 90 / UN5.2.3.1 / PPM / KP-DPRM / 2018 DRPM grant. 


\section{References}

Bhowmik, Sharit K., (2005). Street vendor in Asia: a review. Economic and Political Weekly, May, 28 June 4, 2005, page 2256 - 2264

Chiesura, Anna, (2004). The Role of Urban Parks for the Sustainable City, Landscape and Urban Planning, 68 (2004) 129-138

Gehl, Jan; Gemzoe, Lars, (1996).Public Space - Public Life. Copenhagen: The Danish Architectural Press and Royal Danish Academy of Fine Arts School of Architecture Publishers

NasutiondanZahrah, (2013). Neighborhood Open Space and Quality of Life in Low Income Settlement, Proceeding Int. Seminar Habitechno: Innovation Housing and Settlement Technology

Nasution AD, Zahrah W, (2014). Community perception on public open space and quality of life in Medan. Indonesia. Procedia - Social and Behavioral Sciences 153 $585-594$

Njeru, Anthony Murithi; Kinoshita, Isami, (2018). Evaluating the Significance of Car-Free Streets in Developing Countries: The case of Nairobi, Kenya.Asian Journal of Behavioural Studies (AjBeS), 3(14) Nov / Dec 2018 (p.13-29)

Permana, ArivaSugandi; Aziz, NorsiahAbd; Siong, Ho, Chin, (2016). Leadership styles: Incentive or disincentive approach in addresing street vendor problems in Jakarta and Bandung, Indonesia, Planning Malaysia: Journal of The Malaysian Institute of Planners. Special Issue IV 2016, page 45-60

Rahman, Norhafizah Abdul; Shamsuddin, Shuhana; Ghani, Izham, (2018). Factors Determining Usability of the Streets, Asian Journal of Behavioural Studies (AjBeS), 3(12) Jul / Aug 2018 (p.73-80)

Sun, Ziwen; Bell, Simon; Scott, lain, (2018). Understanding a Specific Walkable Space via the Phenomenon of Chinese Street Vending: An actornetwork theory analysis. Asian Journal of Behavioural Studies (AjBeS), 3(13) Sep / Oct 2018 (p.190-200)

Widjajanti, (2016). The Space Utilization by Street Vendors Based on the Location Characteristics in the Education Area of Tembalang, Semarang. Procedia - Social and Behavioral Sciences227: 186 - 193

Zahrah, Wahyuni, (2016). KoridorRuang Kota LayakHuni :Budaya "Merampas" RuangPublik?, ProsidingTemullmiah 2016 IPLBI / IkatanPenelitiLingkunganBinaan Indonesia, Malang, 2016 